\title{
Roles of Subsidiaries to Parent and Motivations Justifying Their Presence in Developing Countries (DCs): Synthesis of Literature
}

\author{
Alexis Abodohoui ${ }^{1}$, Bolarinwa Osunlalu' ${ }^{2}$, Nie Guihua ${ }^{1}$ \\ ${ }^{1}$ School of Management, Wuhan University of Technology, Wuhan, China; ${ }^{2}$ United Nations Economicand Social Commission for \\ Asia and Pacific. \\ Email: abodohouialexis@yahoo.fr, osunlalu@un.org,niegh@whut.cn
}

Received July, 2013

\begin{abstract}
This paper reviews different policies and looks in some detail at the factors influencing the choice of development of subsidiaries in developing countries. It shows also that the subsidiaries play an important role to the MNC units. We review in this paper some of motives for international transfer, control, coordination, investment, and development of new capability. This research highlights the peculiarities in African business world and improves the strategies about the optimization of the investment in developing countries.
\end{abstract}

Keywords: Subsidiaries; Parent; Motivations; Developing Countries

\section{Introduction}

The strategic decision of internationalization has been an undermined subject matter that continues to fuel the field of knowledge in International Management. Several determinants may be taken into account in the choice of entry of the company in the international market. These factors whether order micro or macro-economic participate in the creation of one or more subsidiaries abroad. Indeed, for many economic and strategic reasons related to the development and business management, such as access to a new markets and growth, companies often create ramifications of their entity at various points of a territory or abroad.

The development of these subsidiaries is crucial for multinationals. At the heart of a period of economic turbulence, globalization and the new division of Labor, several multinationals companies adopt a plethora of strategies to operate in the international markets. It is a fact, on the one hand that many researchers in the field of International Management, agree to admit that subsidiaries play a crucial role in the development of multinational and can be considered as a center of excellence $[2,3,18]$. This idea draws its essence from the various theories on the changing roles of subsidiaries in time and space. On the other hand, we also identified in the literature minimal research on the main motivations of multinationals over their implementation in developing countries [10]. While empirical studies have shown that sub- sidiaries in developing countries facilitate knowledge transfer from industrialized countries to developing ones, others argue that it is more specifically the use of natural resources for the benefit of the parent, minimization of production costs, or the penetration into new markets[10]. Thus, we seek to synthesis and discover the actual roles and motivations of multinationals in developing countries. Seemingly, the reality in these theories remains ambiguous, contested and does not guarantee the role of subsidiaries in economic growth and sustainable development as deemed desirable in developing countries.

To do this, we will first spend the first part about the relationship between the parent has with its subsidiary after a broad definition of both concepts. Then we examine the motivations underlying the establishment of subsidiaries in developing countries for the multinationals and the host countries in order to generate positive externalities. Finally, our last part will allow us to open up opportunities for future research that will feed this field untouched research.

\section{Conceptualization of Multinational and Subsidiary}

To better understand the two concepts it is imperative to offer a clear definition. Prosaically, the subsidiary is a company with at least half of the share capital is owned by another company. This participation enables the parent company to exercise control over the company. The 
subsidiary is generally regarded as company with a percentage of the share capital belongs to a company called parent. The subsidiary is above all a company with legal personality, which can take various legal forms. It is therefore important to distinguish the subsidiary from and the branch is "any commercial establishment in the dependence of a principal business of which he is legally part, has a sustainable manner, in separate rooms, an activity similarly, enjoying a certain autonomy in the economic and business world. The branch does not have legal personality. A multinational, transnational or parent is a company established in several countries through subsidiaries; it owns all or part of the capital. In the recent literature, the multinational is increasingly seen as a global network of subsidiaries scattered, poorly differentiated and controlled from the parent. Other authors define it as "a group of geographically dispersed organizations with different goals and that includes the headquarters and the different national subsidiaries" [15].

A multinational organization is one that operates in a global environment on the one hand, with a need to coordinate its remote operations. On the other hand, it also consists of a set of organizations that operate in different national environments. These definitions lack precision that can only be perceived by linking the two concepts.

\section{Relationship between the Subsidiary and its Parent}

Compared to the relationship parent / subsidiary, the literature has focused on specific factors such as the level of autonomy, formalization, control and their impact performance of the subsidiary. Subsidiaries play very diverse roles in the multinational. Subsidiaries involved in the transfer of resources (knowledge, financial and material). Table 1 allows us to better identify the relationship or dependency ratio and / or interdependence between the parent company and its subsidiary. The subsidiary - parent relationships can be viewed from the perspective of agency theory. Management headquarters (the principal) implements controls the management of the foreign subsidiary (the agent) to prevent it takes do not conform to its own interests decisions.

\section{Summary Evolution of Internal and External Roles of Subsidiaries}

Until recently, multinational innovations come from the North to the South and in turn the parent company to the subsidiary. However, business development and internationalization unprecedented firms today allow us to say or assert that this innovation is multidimensional and multi-platform. They also emanate from the affiliate of the multinational and even the external environment of the production units or services. In support of this idea, several authors have argued that the existence of the house depends on its ability to internal knowledge management and external market mechanisms [11]. The subsidiary is seen as a center of excellence for its place in the development of activities within the multinational. This pole is defined as an organizational unit that includes a set of capabilities explicitly recognized by the company as an import source of value creation, with the intention that the supreme capabilities can be exploited and / or broadcast by the other parties of firm [14]. The following table allows us to understand and identify the different roles of the subsidiary in the capacity of the parent company.

Table 1. Degree of relationship between parent and subsidiary.

\begin{tabular}{|c|c|c|}
\hline Perspective & Definition & Relationship \\
\hline Competitive Advantage & $\begin{array}{l}\text { The multinational is a competitive advantage by locating and } \\
\text { coordinating overseas activities of its value chain [22]. }\end{array}$ & Coordination \\
\hline $\begin{array}{l}\text { Cultural and } \\
\text { Sectorial diversity }\end{array}$ & $\begin{array}{l}\text { A multinational works in more environments and responds to a complex set of factors: } \\
\text { multiculturalism, geographical dispersion of its units and the disparity of its objectives [1]. }\end{array}$ & $\begin{array}{l}\text { Dispersion cultural, } \\
\text { geographic and strategic }\end{array}$ \\
\hline Turnover & $\begin{array}{l}\text { Multi-nationality is based on the percentage of foreign sales to total sales of the entity, the } \\
\text { percentage of foreign assets to total subsidiaries }\end{array}$ & Productivity \\
\hline $\begin{array}{l}\text { Organization and } \\
\text { Management }\end{array}$ & $\begin{array}{l}\text { For [21], multinational may be ethnocentric (now turned to his country), polycentric } \\
\text { (the company implements its subsidiaries in many countries) or geocentric (the implements } \\
\text { business-oriented global market considers subsidiaries as a whole). Multinationals are } \\
\text { characterized by a distribution of resources and delegation of responsibilities to } \\
\text { subsidiaries in the host country [17]. }\end{array}$ & $\begin{array}{l}\text { Degree of processing and } \\
\text { distribution of resources }\end{array}$ \\
\hline Knowledge Transfer & $\begin{array}{l}\text { The company has been presented as a vehicle for organizational learning and organizational } \\
\text { knowledge accumulation [13]. }\end{array}$ & $\begin{array}{l}\text { Mutual transfer of } \\
\text { organizational practices }\end{array}$ \\
\hline
\end{tabular}


They also emanate from the affiliate of the multinational and even the external environment of the production units or services. In support of this idea, several authors have argued that the existence of the house depends on its ability to internal knowledge management and external market mechanisms [6-11]. The subsidiary is seen as a center of excellence for its place in the development of activities within the multinational. This pole is defined as an organizational unit that includes a set of capabilities explicitly recognized by the company as an import source of value creation, with the intention that the supreme capabilities can be exploited and / or broadcast by the other parties of firm [14].

The Table 2 allows us to understand and identify the different roles of the subsidiary in the capacity of the parent company.

\section{Paradoxical Motivations in Developing and Emerging Countries and Emerging}

In the country as a whole is generally a foreign investment component of strategic development. This means that foreign investment in a country generate cash flow and can act as an economic catalyst. It is obvious that investment promotes the transfer of technology and skills and also participates in the formation of human capital. The subsidiary of a multinational can be a facilitator for the introduction of new forms of dynamic management.

These investments therefore encourage many benefits or externalities (spillovers) to the host country. Externalities are mainly indirect effects that benefit local businesses when they are not fully captured by the foreign investor.

Recent studies by the United Nations (Table 3) and specifically specialized institutions such as the United Nations Development Program (UNDP, 2011) and the United Nations Conference on Trade and Development [26] have shown that FDI has increased in developing countries but show that the main driver of these investments is the research or the need for natural resources. Table 3 above gives an overview on the distribution of FDI in developing countries. These improvements are the results from the regulations in the country of origin of investment, the liberalization of the capital account, signing agreements on trade, investment and taxation and various incentives.

Table 2.

\begin{tabular}{lll}
\hline Roles & Determinants & Theoretical Perspectives and Visions \\
\hline Internal & $\begin{array}{l}\text { Absorptive capacity of knowledge, transfer of good } \\
\text { practices between the subsidiary and the parent to } \\
\text { stimulate innovation }\end{array}$ & $\begin{array}{l}\text { Theories based on resources[23-18-28]. Economic transaction costs [27] } \\
\text { Transfer of Knowledge and Skills [16-3-14-28] } \\
\text { acquisition of new benefits and new capabilities }\end{array}$ \\
& $\begin{array}{l}\text { Communication (in all forms) inter-subsidiary and the } \\
\text { parent company, determination and goals set by the } \\
\text { parent company to the subsidiary }\end{array}$ & Achievement of the main objectives of the subsidiary [5-6]. \\
& $\begin{array}{l}\text { Recruitment of qualified personnel, access to foreign } \\
\text { talent and differentiated technologies, increasing } \\
\text { proximity to customers, development of new products, } \\
\text { legal incentive }\end{array}$ & Market factors [8-9].Technological factors [14]. Institutional factors [7]. \\
\hline
\end{tabular}

Table 3. Share of FDI projects by BRIC countries, by host region, average 2005-2007 (pre-crisis period) and 2011 (Per cent).

\begin{tabular}{|c|c|c|}
\hline Partaer region/economy & $\begin{array}{c}2005-2007 \\
\text { [avera ge\} }\end{array}$ & 2011 \\
\hline World & 100 & 100 \\
\hline Developed countries & 41 & 34 \\
\hline European Union & 18 & 14 \\
\hline United States & 9 & 5 \\
\hline Developing economies & 49 & 57 \\
\hline Africa & 9 & 11 \\
\hline Asia & 30 & 31 \\
\hline East and South-East Asia & 13 & 22 \\
\hline South Asia & 5 & 2 \\
\hline West Asia & 11 & 7 \\
\hline Latin America and the Caribbean & 10 & 15 \\
\hline Transition economies & 10 & 8 \\
\hline \multicolumn{3}{|l|}{ Memorandum } \\
\hline BFic & 8 & 11 \\
\hline
\end{tabular}

Source: UNCTAD, FDI / TNC database. 
The real paradox is that these investments are accompanied by a real economic development of countries. There are other incentives factors that lead firms to locate developing countries are summarized in Table $\mathbf{4}$ below. It is clear that developing countries put in a great deal of efforts in order to promote the development of subsidiaries in the country but the real motivations of investors are often far from reconciled with those of national hosting subsidiaries

\section{Discussions and Future Research}

Since the 80s, several strategies have been undertaken to conquer the international market. Sometimes it may be from the same subsidy policy from the country of origin of the company or incentive on the part of host country policies in order to attract the investment. The general finding for understanding the subsidiaries in developing countries are more driven by the creation of competitive advantage and provide centers of excellence for the economic development of the parent company. Many researches have proved undoubtedly that the subsidiaries in developing countries contribute to the likely reduction in the unemployment rate but nevertheless, they do not play a major role in the economic dynamics. Further research allows us to analyze the relationships between the entities required to maintain them. The parent maintains intra-organizational relationships with its subsidiaries. As it is shown that both the subsidiary is a center of excellence for the development activities of the multinational, it is unclear that this division continues in this spirit. The center of excellence provides to the subsidiary many household activities and other subsidiaries. This may be detrimental to the control power of the parent company. Research in this direction should be developed in order to promote the control of the dyadic relationship between these entities. It should be added that the center of excellence for which it qualifies also depends on the degree of local competition. De facto, it is not a confirmed case but depends on several factors and parameters that need to be clarified.

In relation to the transfer of knowledge and technology between the parent and the subsidiary, studies have shown that the parent usually transfer older technologies and especially when there is a threat of the latter at the country level Home. This fact contributes to the balanced development of the understanding of the technology in the country of origin or those who receive. Other research analyzes the development of the subsidiary in the developing countries participate in the industrialization of the country but then forgets the positive feedbacks that should raise Foreign Direct Investment in these countries. Other factors are not conducive to the development of local subsidiaries. We can cite among others, government corruption in developing countries, the administrative difficulties, problems of insecurity, crisis emanating from poor governance at a national and global level,, expropriations are bottlenecks for the development of economic activities. These factors are studied carefully in order to showcase sustainable development in developing countries and not to mention a fight against tax evasion.

While existing institutional agreements are positioned to strengthen key national policies to maximize the benefits of FD, It is important to seek to preserve a national discretion to allow developing countries, within their international obligations, to pursue policies that contribute to their development. This is how and to what extent international investment agreements can be designed to foster development. This is an issue that deserves attention especially at a time when each host country means to attract FDI and benefit from it. Analyzes can be gone in the direction of how developed countries can help developing countries and countries in transition in their efforts to attract FDI. This analysis in this direction can be very fruitful.

The internationalization and development subsidiaries also assume the management of diversity and recognition of subcultures. Any country or region must implement strategies for creating a unique culture of "global citizenship" cosmopolitan entrepreneurs and executives. Cultural tolerance, and recognition of their flexibility allows operation in various uninhibited environment or frustrations. Effects must also be taken in this field of research that is becoming more and more complex rhythm of many theories and paradigms developed in order to apprehend it.

It is an international technology transfer internalized and externalized transfer, it is important for the host country to determine which of the two modes can have a positive impact on its economy. For multinationals choose the mode of transfer to a non-trivial inclination

Table 4. Analysis of factors related to the actual establishment of subsidiaries in developing countries.

\begin{tabular}{llll}
\hline & Incentives factors & Attraction factors & \multicolumn{1}{c}{ Management factors } \\
\hline $\begin{array}{l}\text { Sources of creating } \\
\text { subsidiaries in the } \\
\text { host country }\end{array}$ & $\begin{array}{l}\text { Narrowness of the domestic market; } \\
\text { Internationalization policy of the company; } \\
\text { Development of commercial synergies; } \\
\text { Imitation of competitors; Technologies transfer }\end{array}$ & $\begin{array}{l}\text { Low production costs; } \\
\text { Access to natural resources; } \\
\text { Institutional incentives authorities } \\
\text { of the host country }\end{array}$ & $\begin{array}{l}\text { Successful internationalization and } \\
\text { assembling alliances (joint venture, } \\
\text { acquisition, Greenfield, Fusion ...) }\end{array}$ \\
\hline
\end{tabular}


but are based specifically on certain variables such as nature and pace of technological change, the nature of the subsidiary, the industry and certain features and policies host country. It can also be no question local competitive environment in which the subsidiary operates.

\section{REFERENCES}

[1] Adler and J. Nancy, "Globalization, Government, and Competitiveness,” Optimum, 1994, Vol. 25, No. 1, pp. 27-34.

[2] Andersson, Ulf/Forsgren, Mats, "In Search of Centre of Excellence: Network Embeddedness and Subsidiary Roles in Multinational Corporations,” Management International Review; Fourth Quarter 2000, Vol. 40, No. 4, ABI/INFORM Complete pg. 329.

[3] A. Phene and P. Almeida, "Innovation in Multinational Subsidiaries: The Role of Knowledge Assimilation and Subsidiary Capabilities," Academy of International Business, 2008.

[4] C. A. Bartlett, S. Ghoshal, "Transnational Management: Text, Cases and Readings in Cross-Border Management," 3rd edition, Boston: Irwin McGraw Hill, 2000.

[5] Balogun, P. Jarzabkowski and E. Vaara, "Selling, Resistance and Reconciliation: A Critical Discursive Approach to Subsidiary Role Evolution in MNEs," Journal of International Business Studies, Vol. 42, 2011, pp. 765-786. doi:10.1057/jibs.2011.13

[6] J. Birkinshaw, et al., "Consequences of Perception Gaps in the Headquarters-subsidiary Relationship," International Business Review, Vol. 9, 2000, pp. 321-344. doi:10.1016/S0969-5931(00)00004-4

[7] J. M. Birkinshaw and N. Hood, "Multinational Subsidiary Development: Capability Evolution and Charter Change in Foreign-owned Subsidiary Companies," Academy of Management Review, Vol. 23, No. 4, 1998, pp. 773-796.

[8] J. Cantwell, “A Theory of Technological Competence and Its Application to International Production," in D. McFetridge, ed., Investment, Technology and Economic Growth, Calgary: The University of Calgary Press, 1991 pp. 93-109.

[9] V. Chiesa and C. Masella, "Searching for an Effective Measure of R\&D Performance," In Proceedings, 2nd International Product Development Management Conference, Gothenburg, Sweden, 30-31 May1994, Brussels: European Institute for Advanced Studies in Management.

[10] S. Chiraz et al., "Extension Du Rôle Des Filiales Occidentales Implantées Dans Les PED: Les Facteurs Déterminants,” Université Laval, Québec, 2004.

[11] J. Dunning, "The Geographical Sources of the Competitiveness of Firms: Some Results of a New Survey," Trans- national Corporations, 1996, Vol. 5/3, pp. 1-29.

[12] J. H. Dunning, "Multinational Enterprises and the Global Economy,” UK, Edward Elgar Publishing Limited, 2008.
[13] K. Eriksson, J. Johanson, A. Majkgård and D. D. Sharma, "Effect of Variation on Knowledge Accumulation in the Internationalization Process," International Studies of Management \& Organization, Vol. 30, No. 1, 2000, pp. 26-44.

[14] T. Frost, J. Birkinshaw and P. Ensign, "Centers of Excellence in Multinational Corporations," Strategic Management Journal, Vol. 23, No. 11, 2002, pp. 997-1018. doi:10.1002/smj.273

[15] S. Ghoshal and C. A. Bartlett, "The Multinational Corporation as an Interorganizational Network," Academy of Management Review, Vol. 15, No. 4, 1990, pp. 603- 625.

[16] I. Martinkenaite, "Antecedents of Knowledge Transfer in Acquisitions,” Baltic Journal of Management, 2012, Vol. 7, No. 2, 2012, pp. 167-184.

[17] J.-L. Mucchielli, Multinationalisation et Mondialisation. coll. Points, éd. du Seuil, 1998, p. 372.

[18] B. Kogut and U. Zander, "Knowledge of the Firm and the Evolutionary Theory of the Multinational Corporation," Journal of International Business Studies, Vol. 34, No. 6, 2003, pp. 516-529. doi:10.1057/palgrave.jibs.8400058

[19] Leong, S. Meng and C. T. Tan, "Managing Across Borders: An Empirical Assessment of the Bartlett and Ghoshal Typology,” Journal of International Business Studies, 1993, Vol. 24, No. 3, pp. 449-464. Reprinted in Marketing Insights for the Asia Pacific, Singapore: Heinemann Southeast Asia, 151-166.

[20] Moore, Karl, "A Strategy for Subsidiaries: Centres of Excellences to Build Subsidiary Specific Advantages," Management International Review, July 1, 2001.

[21] H. V. Perlmutter, "The Tortuous Evolution of the Multinational Corporation,” Columbia Journal of World Business, Vol. 4, 1969, pp. 9-18.

[22] M. E. Porter, Competition in Global Industries, New York, 1990 : Harvard Business School Press.

[23] C. K. Prahalad and G. Hamel, "The Core Competence of the Organization,” Harvard Business Review, Vol. 68, 1990, pp. 79-91.

[24] R. Ramamurti and Singh, "Emerging Multinationals in Emerging Markets,” Cambridge University Press, 2009.

[25] D. Sullivan, "Measuring the Degree of Internationalization of a Firm,” Journal of International Business Studies, Vol. 25, 1994, pp. 325-342. doi:10.1057/palgrave.jibs.8490203

[26] Unctad, WORLD INVESTMENT REPORT 2012. Towards a New GeNeraTioN of investment policies. United Nations Publication, 2012.

[27] Williamson O. (1981), The Economic Institutions of Capitalism, New York, Free Press.

[28] V. Zander and B. Kogut, "Knowledge and the Speed of the Transfer and Imitation of Organizational Capabilities: An Empirical Test,” Organization Science, Vol., 6, 1995, pp. 76-91. doi:10.1287/orsc.6.1.76 